\title{
DEPARTMENT OF PUBLICATIONS
}

\section{BOOK REVIEWS}

Organized Efforts for the IMprovement of Methods of AdMinstration IN THE UNTTED States. By G. A. Weber. New York: D. Appleton and Company. For the Institute for Government Research. Pp. 391.

This book is a recognition of the increasing technical character of government, and is a description of the public and private efforts to make governmental processes effective. In particular the writer deals with governmental research and legislative reference which is concerned with the technique of administration rather than with the larger problems of politics.

For the national government, Mr. Weber traces the examination and improvement of administrative machinery from the earliest congressional inquiries through the current efforts of the United States bureau of efficiency (official) and the institute for government research (citizen).

In the feld of state government there is a discussion of the several temporary state commissions on economy, efficiency, and reorganization, official boards of administrative control, and a few permanent citizen organizations working to the same end. Supplementing this is a description of the services rendered by official legislative reference and bill drafting agencies.

In the local field-municipal and county-the author enumerates the organizations and some of the results obtained by both official and privately supported bureaus of research.

The volume is intended as a reference book, and does not purpose a discussion of the theory of improving administrative methods, nor to any great extent the results accomplished. As a reference book the minor short-comings,- -almost entirely in the field of local government-are relatively unimportant. Many reference books suffer from obsolescence as they come from the publisher, and undoubtedly the war and industrial disturbances delayed the presentation of this material. A number of recent county and city agencies are omitted, and data relating to certain agencies indicate the status of 1916 . One agency in the national field, organized in 1915, - tho Institute for Public Servicz-is omitted. On the whuls, painsiaking cere has been expended, and the book will be valuable to both the official and citizen concerned in getting more effective government.

In addition to its primary purpose of reference, the volume is also a measure of the distance that one important movement for better government has come. For this latter service it is unfortunate that the material could not have been revised in 1919 that it might have more truly reflected the importance of the efficiency movement, particularly in cities and counties where development has been rapid.

New Towns After the War. An Argument for Garden Cities. London: J. M. Dent \& Sons, Ltd. Pg. 84.

An attractive pamphlet summarizing the objections to haphazard city construction, indicating the advantage to be expected from intelligent town planning, and painting in glowing colors the splendid possibilities of after-war urban developments in Great Britain, has been published under the above title. It seems to take for granted what so many authorities on housing conditions in England now proelaim, that the state, working through local authorities, is to be the sole house-landlord of the future and that while present private owners of housing property in England will continue as landlords until their houses are worn out, their lot will be quite unenviable and that they will undertake no new construction. This would constitute a very long step in the direction of state Socialism. A large proportion of the buildings erected by the government will be rented at figures which mean a net loss to the state, and as the state is, after all, only the associated people, somebody must pay in increased taxes for uneconomic rents. New towns are to be created. The program starts out with the cry, "Build a hundred garden cities!" It even proposes that town authorities build model factories to be let on rental. The suggestion vaguely appears that the increased value of sites shall be utilized for the public good, but the question which has so far stared all such projecs in tie face, namely, where to put these m.jel citics and how to find sites for them which 
will not cost so much that the future of the new community is mortgaged indefinitely, is not even discussed. The price of land in England has advanced enormously since the war. The owners of available sites are aware that hundreds of public authorities are coming into the market bidding for their land. They are informed by pamphlets like this that a million houses must be built within the next five years. In estimating the price to be paid for land the present owner is permitted to demand a price based on its possible future use. It requires little imagination to anticipate what the effect on land prices will be. As there is no relation in England, such as exists, however imperfectly, in America, between assessment of land for purposes of taxation and the selling price of land, one may predict that the result of such a scheme as is here proposed, would be to greatly enhance the fortunes of present owners of the land. Up to the present, the failure of the project is indicated in the most authoritative Journals.

J. J. M.

The Decline of Aristocract in the PoliTICS OF New York. By Dixon Ryan Fox. New York: Columbia University; Longmans, Green and Company, agents. 1919. Pp. 460.

Dr. Fox has given us a detailed history of political parties from 1801 to 1840 . It strikes one with surprise that he starts his study at so late a date. To the student he would have given the satisfaction of a perfect sequence if he had begun where Dr. Becker left off in his history of the Political Parties in the Province of New York, $1760-66$. It is true, of course, that the "revolution of 1801" overturned a government of "the rich, the well-born, and the able," and thus affords a starting point for the description of a waning aristocracy. This description is portrayed to us graphically and not without a touch of humor.

The student of municipal history will be interested particularly in a series of twelve diagrams on pp. 433-35. Under a caption "Who Were the Whigs," the author shows the results of elections by wards in the city of New York from 1810 to 1840 wherein we rediscover that the leopard does not readily change his spots.

Dr. Fox has a way of bringing us very near to the personality he is portraying, as when he writes of the delegates to the convention of 1821 , and again of the "Albany Regency" of 1823. $H$ is footnotes everywhere give evidence of the extensive reading upon which conclusions have been based.

It is possible that the work could have been improved at many points by the use of shorter sentences. Such minor defects should not be overemphasized, however, in a treatise that is so thoroughly satisfying and interesting. The monograph is appropriately illustrated with portraits gathered from unusual as well as authentic engravings or paintings, and it has an admirable index.

A. Everetr Peterson.

\section{REVIEWS OF REPORTS}

Thirty-Fourth Annual Report of the Board of Gas and Electric Light Commissioners of Massachusetts, for the Year I918.-This report, for the calendar year 1918, covering statistics for the year ending June 30,1918 , is a fat volume of 800 pages, which well maintains the reputation of this, the oldest public utility commission in the United States, and, in fact, in the world. Its chief value consists not so much in the decisions, the year's legislation, and the few pages of general introduction, as in the extensive reports of the various gas and electric companies of the state. No other commission, with the exception of the New York commissions of the first and second districts, presents statistical and financial data in as clear and systematic a manner as does this Massachusetts commission.
There are also some valuable statistics of the four municipal gas plants and the thirty-nine municipal electric light and power plants in the state. But with the exception of the gas plants of Holyoke and Westfield and the electric light plants of Holyoke, Taunton and Chicopee, these plants are too small to be of general interest.

From the data given in this volume it can be computed that the fifty-nine private gas companies increased their sales to private consumers from $18,046,000,000$ feet in the year ending June 30,1917 , to $19,530,000,000$ during the following year, or over 8 per cent. The revenue from private consumers, and from cities for street lamps and public buildings, increased from 86 cents to 92.4 cents while the profits available for interest, dividends and surplus de- 